\title{
Fundamentalism as a Specific Form of Islamism
}

\author{
Antonello Canzano \\ University "G. d'Annunzio" of Chieti-Pescara, Pescara, Italy \\ Email: a.canzano@unich.it
}

How to cite this paper: Canzano, A. (2019). Fundamentalism as a Specific Form of Islamism. Advances in Applied Sociology, 9, 379-391.

https://doi.org/10.4236/aasoci.2019.98028

Received: July 15, 2019

Accepted: August 18, 2019

Published: August 21, 2019

Copyright (c) 2019 by author(s) and Scientific Research Publishing Inc. This work is licensed under the Creative Commons Attribution International License (CC BY 4.0).

http://creativecommons.org/licenses/by/4.0/ (c) (i) Open Access

\begin{abstract}
The article is taken as its starting point from the concept of "strong religion" in which the phenomenon of fundamentalism develops trying to circumscribe it in its specific theoretical and practical sphere, analysing its genesis, the modalities of development and its consequences. The fundamentalism is often used in reference to things and facts that have little to do with what is authentically meant by fundamentalism. First of all it is our task in this article to understand the true nature and possible consequences of fundamentalism in our age. The analysis that is developed in this article mainly refers to fundamentalism in the Islamic context, presenting Islam as a specific form of fundamentalism in its main characteristics: structural, ideological and organizational. Finally, one wonders if another Islam is possible and if it is able to prevail, stopping the current trends in terms of radicalization and violence.
\end{abstract}

\section{Keywords}

Religion, Fundamentalism, Islam

\section{Introduction}

The purpose of this paper is to analyse the phenomenon of fundamentalism in Islam. It is not supposed to give an all-encompassing picture of the entire phenomenon, as it will just cover its most typical characteristics and extent. In the path developed in this article it particularly highlighted the specificity of the fundamentalist phenomenon that develops in relation to a specific religious tradition, mainly stimulated by the comparison with modernity, cultural and socio-political pluralism. The analysis that follows will assume fundamentalism as a phenomenon that although related to a religious tradition, is configured mainly as a radical political-ideological event that is antagonistic to the "external world" associated with the idea of the enemy and in which the main resources are established by the leader's charisma and internal mobilization.

From a general point of view, religious fundamentalism requires a "strong re- 
ligion" as the host or, better said, to feed off of, as it aspires to extend its hegemony across the entire organisation. This, in the case of the Islamic world, is all the more true since within its majority component, Sunnism (almost $90 \%$ of the entire Muslim world), the structural weakness leaves room for fundamentalists to claim control over the whole religious community, especially due to the lack of a hierarchy that supervises it as an official doctrine. With regard to Sh'ism, despite having a semi-hierarchical structure, Khomeini's revolution had already transformed it into a fundamentalist element capable of establishing an Islamic theocracy with a totalitarian imprint as early as 1979. In both cases, fundamentalism can be considered as a specific and well-defined phenomenon, not to be confused with other phenomena which can generate from it, such as Islamist terrorism. Indeed, one of the most common errors in the contemporary debate is conflating fundamentalism as a whole with terrorism. The latter may stem from or be inspired by it, yet it is a phenomenon per se. Undoubtedly fundamentalism can help to generate it, as in the case of Islamist terrorism, but it then becomes something separate with its own specific features, stressing that in most cases this is not happening, such as in Christian and Jewish fundamentalism. This does not mean that they cannot include the extreme option of violence and death, but it is something different from the actual phenomenology of terror. Rather, religious fundamentalism gives rise to movements that are highly focused antagonists of secularisation and, in the case of Islamism, embraces the extreme rejection of modernity and its advocates, standing as defenders of truth, and the guardians of the foundations of true faith and tradition. It is a reactive phenomenon that seeks to counteract the erosion of religion's significance in public and social life by claiming its coercive character linked mainly to the imposition of an orthopraxy. In this sense, Islamic fundamentalism is seen as a political-religious ideology founded on a specific setup with organisational resources. In a word, we are talking about an identity phenomenon which tries to set the boundaries of its own community and defend it against potentially destructive enemies. This can be achieved by establishing a strongly authoritarian structure and finding an absolute enemy to engage.

This analysis will also seek to identify what can be considered as the prelude to Islamic fundamentalism, meaning the particular characters of Islam that expose it to the rise of radical ideas, due to its intrinsic politicisation. Finally, it will be analysed whether fundamentalist Islam is so indisputable and can really be a successful alternative within the Muslim world, or whether other visions can resist and hold it back effectively.

\section{The Prelude to Fundamentalism}

The use of religion for political ends is not righteousness but idolatry (Sacks, 2015). Yet, it seems that the historical and religious path taken by a specific segment of Islam inevitably leads to politics.

First and foremost, we must distinguish the word "Islam" from "Islamism", 
which are often erroneously used interchangeably and confused. Islamism is indeed an aspect of Islam as a whole, though it cannot be fully referred to the latter, nor can it be assimilated to it.

Islamism, or political Islam, is instead one of the political-religious ideas that have "cyclically" emerged throughout Muslim history, claiming the monopoly on the orthodoxy of this religion which pays for the absence of custodians of dogma recognised unanimously as such. In this sense, Islamism aspires to an actual "Muslim redemption", if possible through a universal and all-embracing conception of Islam, thus remedying this "religion without a centre" (Guolo, 1999: p. 10).

For a better understanding of the concept of political Islam, it is necessary to start from the essential lesson by Juan Linz, a milestone in the analysis of the relations between religion and politics. Linz introduces the basic distinction between "political religion" and "politicised religion" which are the two different ways non-democratic regimes legitimise their system of government. Separating these two concepts is of the utmost importance, and so respectively distinguishing the use of religion by the totalitarian western governments of the 20th century from the non-democratic Islamic governments, whose extreme manifestation was the Iranian Khomeini's and post-Khomeini's theocracy, and later the forms of theocracy linked to various factions within Sunni Islamism, such as the Afghan regime of the Taliban and the self-proclaimed Salafi inspired Islamic State, now defeated territorially. Linz makes an intentional distinction between the religious use of politics and the political use of religion. In the first case, political religion can prevail because of the conflicting separation between Church and State, as opposed to the liberal instantiation of the consensual separation of these two areas. The State tries to confine religion to the private sphere of the individual, replacing it with secular role models-the totalitarian communist and nazi ideologies-which are also imposed in the public religious life. In this sense, political religions are actual pseudo-scientific religious surrogates battling pre-existing religious traditions to the point of cancelling them. By rejecting any concept of transcendence, they should not be considered as different religions, rather as non-religions generating from the secularisation process underway in the West, thanks to the advent of mass society. In the second case, instead, politicised religion prevailed because of the political leaders' will to politicise the existing religion, turning the State into a confessional state. Far from being separated, politics and religion are strongly connected: it is precisely because of this close bond that religion lends itself to legitimising not so much the existing social order, but, more specifically, a certain political regime and the political community of reference. Pushed to the extreme, religion becomes an ideological surrogate in support of political leadership. As already mentioned, this is still the case today in Iran, where political power is exercised by the government in the name of God with the aim to create a community - the ummah-based on religious affiliation only. Although there is a certain analogy between theocracy and 
political religion due to interpenetration, in both cases, be it of political or religious elements in the definition of authority, in a theocratic system it is proclaimed in the name of a body of beliefs supported by religious leaders. It is not the outcome of a political process during which power rests with political leaders. This is why political religions are weaker than politicised ones: the use of religion for political ends is, in fact, the oldest known strategy used within certain political regimes and, above all, survives their fall; whereas, political religions rise hand in hand with a political movement and within a political system, and are destined to disappear with them. Finally, supporting the regime through a politicised religion that relies on transcendent values is certainly less costly for rulers, especially when such politicisation is backed by sincere religious reasons on the part of large strata of society socialised in the faith. Consensus can therefore be built out of shared values rather than coercion, which is generally necessary for political religion. Therefore, compared to the latter, politicised religion will last longer and better (Linz, 2006: pp. 95-126).

Linz's masterful lesson sheds light on the analysis of the relationship between religion and politics in Muslim countries, considering that the peculiar relationship resulting therefrom is now far removed from Western interpretative categories determined by a development of civilisation, in itself marked by secularism and modernity.

In fact, what happened in the West-and still happens today-is that religious reflection is directed towards political arguments; the latter, however, must be brought back into the realm of theology first, with the political sphere having an accessory function.

It is the agreed separation between spiritual power and temporal power typical of liberal regimes that marks the line, however subtle, between the two spheres. Indeed, the relationship between Church and State reduces the interference of religious authorities in the political sphere, just as the intervention of political power in the religious dimension is limited. This ensures a certain balance between the two fields and, where there are forms of cooperation between them, their mutual autonomy is still guaranteed. On the one hand, the State will not be able to impose a secularised society through the unilateral definition of common values and goals; on the other hand, the Church will not be allowed to eradicate the secular character of the State on the basis of a supreme authority of a divine nature.

As for Islam, which is indeed a religion, it is quite hard to analyse it from a purely theological standpoint: God is one and transcendent ["There is nothing like unto Him": Quran surah 42, 11]; He is the absolute and almighty ["He is Allah, [who is] One"; "Allah, the Eternal Refuge"; "And there is none like unto Him": Quran surah 112, 1-2-4] and therefore cannot in any way be a subject of study.

This does not mean that throughout the history of Islam no strictly theological disciplines have flourished, but, more importantly, that Islam is, unlike the other 
monotheistic cults that preceded it, not only a religion, but "an orthopraxy, a doctrine of ethics and behaviour, dominated by the presence of a sublime and perfect God [...], but directed specifically to the mundane world" (Campanini, 1999: p. 7).

To reinforce this argument, "the Quran [...] can be understood as a practice. [It] is not simply a practical guide to organising the life of individuals and communities; it is the operations science of society inasmuch as it itself established through the real movement which [...] allows all mankind and humans as individuals to rediscover their authentic meaning. History has one meaning, only one: the Quran [therefore] represents God's instructions to make History" (Etienne, 2001: p. 37).

It is therefore plain to see that political issues in Islam are far more intertwined with religion than the theological ones are, and that politics plays a prominent role as opposed to pure theology, so it is inevitable to subject political and governance issues to the revealed Law (shari ah). "Only in the continuous confrontation with the word of God does the human world assume a value and a meaning, even in those aspects that we are accustomed to consider 'secular'; it is evident that this implies the constant reference to sacred texts and to the example of the prophet Muhammed, but it also implies that there is no political philosophy without religious approval" (Campanini, 1999: pp. 7-8).

It is certainly not unrealistic to define the Quran as a political work, considering that the essence of politics resides, or at least can be sought, in religion. And, "unlike the Torah, the Christian Bible, the Gospels, the Quran is not a 'chronicle of events' or a collection of legal provisions. More fundamentally, it is the set of rules of every Muslim's political, social, family and religious life [...]. The very same conditions of the Prophet's struggle to impose himself make the Quran an eminently political text. The fact that he had to first conquer the Arabs and then face migration (hiğra) as a result of his initial failure, led to a radical cut that would produce an essential change: the Prophecy elevated to a Code" (Etienne, 2001: p. 41). Finally, making a further comparison with the other monotheistic religions, "Islam proposes a project of ideal City apparently comparable to the Jewish and Christian utopias", which in this sense is an eschatological project. But, unlike the other utopias, the actual ideal Islamic City is realised in the work of the Prophet and the first four caliphs, the so-called "Rightly Guided Caliphs" (râshidûn) (Ivi, 43-44).

\section{The Structure of Islamist Fundamentalism}

The ideal Islamic city in Islamism is about the indissolubility of the relationship between politics and religion according to Linz's meaning of politicised religion, and leads to a prevalence of the "categories of politics" which are policies where the distinction between friend and enemy is prominent. "The meaning of the distinction between friend and enemy denotes the utmost degree of intensity of a union or separation, of an association or dissociation. It can exist theoretically 
and practically, without having simultaneously to draw upon all those moral, aesthetic, economic, or other distinctions." (Schmitt, 1972: p. 109). According to Carl Schmitt, the enemy is the other, meaning those who, in their otherness, represent "the negation of one's own kind of existence and therefore must be fended off or fought against in order to save one's own, existential kind of life" (Ibid.). Fundamentalism, as a specific ideological setup, represents the extreme degree of belonging to a religious community (ummah), which results in political unity while, at the same time, in a clear partition from those who deny one's own way of existence, which is threatened by secularist and individualist modernity. The inside/outside dichotomy is the dominant theme, which is lexically expressed as light vs darkness (daw/zulumat), truth vs falsehood (haq/batil), the party of God vs the party of Satan (hizb Allah/a' da' Allah, hizb al-shaytan), the sound vs the unsound (salim/marid) (Almond et al., 2006: p. 53). And if darkness, falsehood, the party of Satan, the unsound, etc ... are on the outside, all this can be synthesised with the word modernity (Watt, 1988).

For the fundamentalist forces, the threat of modernity mainly consists in assuming human autonomy as the ultimate principle and end. This principle, which tends to be absolute, is the result of a conception and a culture which, from the Enlightenment onwards, has elevated man to the level of master of his own fate, as he follows rules of conduct in violation of the will of God written down in the prescribed norms (shari ah). This imposes the inside/outside "separation" as a divine imposition from all those who are tolerant towards modernity. And the most important distinctive element capable of marking a "separation" is behaviour, thus admitting that orthopraxy is the true foundation of faith. In order to exist, fundamentalism needs to build strongholds within which the group's cohesion and the compliance with public rules are mainly ensured by the strict observance of the precepts that mark the dividing line. The greater the threat, the more compliant behaviour is, understood as strict observance of the precepts. In this way, not only is purity restored in a contaminated world, but the traditional practices that social change allegedly eroded are also re-established. Their attempt, disguised as an authentic recovery of tradition and its rules, is rather about partially creating from scratch a set of functional rules for an order to be established to fight the compromise with modernity within Islamic communities. Therefore, the task would consist in planning an order to try to reinterpret the tradition while making an innovative attempt to invent a particularly suitable set of laws which mark a clear separation (Ivi, 69-72). In their mind, being simply conservative or traditionalist is not enough. The reality of today's struggle requires new methods, a new ideology and a new organisational system.

Building on Linz's statements, we observe that ideology plays a decisive role, as it makes the fundamentalist attempt a well-defined project of political use of religion. When trying to restore a political-religious order, the first ideological element-or the ideological premise, if you will-to stand out is the reaction to marginalisation of religion, both within society and in the public sphere, as secularisation and modernism pervade the public realm, thus governing the social 
sphere. Religion cannot simply become a private matter.

In order to make its ideological structure effective, fundamentalism uses the principle of selectivity, which serves a dual purpose: firstly, it allows the selection of those aspects of tradition that clearly distinguish the fundamentalists from the majority, whilst clearly using tradition for political ends, which allows to perfectly characterise the community while neglecting the least distinctive features. Subsequently, it tries to enhance this process by selecting those aspects of modernity that are particularly functional to the cause, such as modern communication technologies.

The separation principle also requires a Manichean ideological approach, a dualistic worldview. Good will triumph over evil. In this way, fundamentalism has a particularly effective ideological tool to developing a strong sense of belonging and shelter from contamination from the outside. But it is also able to produce a clearly defined activism and a particular concept of jihâd.

Ideology creates deep attachment if it claims absolutism and infallibility. What has been revealed and what has been reworked or invented since revelation leaves no room for uncertainty or relativity. The rules of religion in the fundamentalist approach are absolute and infallible.

Finally, the political-religious ideology of fundamentalism is imbued with messianism. Good will triumph over evil, just as true believers will win over infidels by obtaining the promised benefits.

Fundamentalism is not only an ideology, it is also an organisational system, and from this point of view it has resources that allow it to trigger important motivating and identity factors. First and foremost, there is the organisational element of member election, which makes members an "elect body" of chosen or divinely called. The concept of election is a powerful tool for fostering group solidarity and cohesion and for stimulating strong psychological motivation. The idea of ummah in fundamentalism is reconceptualised and takes shape from the special status of elect member, and preserves the fundamentals of doctrine in a hostile context. In this context, even the notion of jihâd, understood as striving in the path of God, can be interpreted as more closely related to the quality of the mission taken on by the "elect body".

From an organisational point of view, the "sharp boundary" element is of great significance, as it allows to put separation into practice. It is the boundary between true believers and apostates, between the saved and the damned. This kind of boundary is also a spatial metaphor and is well suited to strengthening the boundary between the inside and outside of the community, where the level of symbolic identification and rigor in the application of the orthopraxy contribute to standardise behaviour and custom. The sharp boundary is what defines ummah and allows it to play that prominent role in social architecture. However, it is difficult for such a phenomenon, which tends towards a clear separation, to succeed if it does not have a charismatic organisation, that is, the specific property which structures the relationship between leader and followers, where 
the leader is granted special access to the divine realm and perfect erudition in the Scriptures. Thanks to this particular organisational characteristic, the Ulemas, especially in Sunni Islam, where traditionally they have never enjoyed a spiritual status, can take a different role, becoming only the moral guide of the community.

Finally, the rules of behaviour, at the organisational level, should not be considered as a mere systematisation of orthopraxy. They actually provide a solution to the problem of authority, by occupying the most important role internally, i.e. the doctrine of the infallibility of the authoritative text, which plays a pivotal role, making the shari ah the founding element of Islamic fundamentalism (Ivi, 133-139).

We can ultimately say that the characteristics on which the entire fundamentalist system rests are reactivity and separation. While reactivity allows us to act against a world perceived as increasingly contaminated and contaminating, whose great appeal increasingly downsizes the religious sphere, separation is essential to restoring communities identified by a faith oriented to the sole correct behaviour. The goal is to conquer the world. And it is precisely this goal that inspired the modern Salafist radicalism which was informed by the theories of Sayyd Qutb, who continued the work of Hasan al-Banna and was influenced by the Pakistani ideologist Abul Ala Maududi. It was the latter who believed that the jâhiliyya (pre-Islamic ignorance), which was contaminating Egypt and calling for its recapture, was then even more dangerous and on a larger scale, considering the strength of the enemy and its capacity for cultural and political propagation. Recapture as a consequence of the Jahiliyyah, which in Qutb's opinion becomes an interpretative category to include all that is outside Islam, must be achieved through fighting, which, by its nature, becomes sacred. In the dichotomous vision of the Egyptian ideologist, therefore, there are no other types of intermediate societies than the Islamic one and the Jahiliyyah one (or simply, "ignorant" society), which are fiercely opposed to each other. In this sense, recapture feels like the revivalism of the Islamic world, which can only stem from the full understanding of and militant adherence to the dynamic sense of the sacred text: Islam-in Qutb's opinion-is, in fact, "a dynamic method of living that only activists and militants can truly understand and interpret”. It is therefore their duty to firmly oppose the decadence of the world by rebuilding the ummah and affirming it as the best one that God has created on earth. Islam, he says, is "a challenge to all systems that assign sovereignty to human beings [...] a revolt against any human situation where sovereignty is given to human beings [...]. Any system in which the final decisions are referred to human beings [...] deifies human beings by designating others than God as lords over men" (Qutb, 1983: p. 60). With Qutb, the Sunni fundamentalist ideology would undergo a qualitative breakthrough as an innovative systematisation able to influence almost all the radical movements and groups that would develop within Sunni Islam thus far. The recapture of the world requires the concept of jihâd to be duly 
rethought and put effectively into practice. For Qutb, recapture corresponds to the main objective of Islam: the leadership over mankind. That is why Islam is forced to fight: jihâd. For the Egyptian ideologist, war is an effort, or rather an individual obligation against the obstacles to preaching, which must be fought collectively in organised movements and groups as strongly united as their opponents, who act through powerful collective organisations such as states and coalitions. Jihâd is therefore a broad and necessary reaction, extended to a global level and assumed permanently. In this way, being a believer means being a warrior, member of a community of warriors led by God Himself as the leader of the battle (Allam, 2000: pp. 271-272).

In fundamentalism, as we have seen, the concept of jihâd assumes a predominantly military meaning, from individual effort to collective war, whatever defensive or offensive it may be. This is exactly how you get to the concept of enemy, which acquires its meaning and becomes a real possibility by virtue of war, as the extreme realisation of hostility. Returning to Carl Schmitt, war creates a specifically political behaviour, and only in real combat is the most extreme consequence of the political grouping of friend and enemyrevealed. And he continues, "a religious community which wages wars against members of other religious communities or engages in other wars is already more than a religious community: it is a political entity" (Schmitt, 1972: pp. 116-120). And even if the hostilities are, for various reasons, ceased or suspended, the enemy remains and therefore the state of war becomes a permanent condition, as if to say: bellum manet, pugna cessat (Ivi, 193).

\section{Is It Possible to Develop a Different Islam?}

The fundamentalism that seems at this stage to take the leadership in the Islamic world, with all the consequences described in terms of political conflict and violence, we ask ourselves whether within the broad and varied Islamic tradition it's possible to locate some currents that aim at affirming a different Islam that favours moderatism-oriented interpretations.

While Qutb declares in his book In the Shade of the Quran that Islam "aspires to peace, but because of the aggressions to which it is subject, it finds itself forced to descend upon the battle field and to use military force" (Ibid.), there are also some who believe that aspiration to peace may be a possible future, and that fundamentalism should not necessarily be the destiny of Islam.

In fact, some scholars reaffirm that the problem of Islam does not lie so much in the theological dimension, but in the type of interpretation that some theorists and religious leaders give to it. "Not surprisingly, Muslims across a broad political spectrum use Islam to serve their own political ends-as religion is often used in other societies. Nonetheless, the structure and historic development of Islamic theology and law does predispose Islam to focus less on individual rights and more on individual obligations and the creation of the 'just society' as a whole" (Fuller \& Lesser, 1996: p. 91). 
Certainly, in Islam there are, at least in theory, some elements that could justify more flexible contemporary interpretations of the Quran and of the Prophet's hadît, with a view to possibly adapting them to the most significant principles of the international legal system in force.

In particular, two available instruments to start this hypothetical Islam reform process are the itihâd-the reinterpretation or extension of judicial precedents-and the ijmâ - the revision carried out with the consent of Islamic law scholars.

"This will happen only if Muslim scholars or the Muslim community at large wishes it to happen, enabling reformist views to replace those of the more literalist or radical interpreters who dominate the Islamist political scene today. Regrettably $[\ldots]$, the reality is that the contemporary Muslim community, in most countries under pressure or crisis from international forces as well as domestic despotism and deteriorating social and economic conditions, is drawn more towards the stark reductionism of the Islamists than toward the more open, more 'Westernized' versions of Islam. People do not usually turn to liberal, less familiar forms of belief or to the spirit of experimentation with deep cultural traditions and values in times of crisis. On the contrary, they are inclined to revert to familiar basics in values and traditions" (Ivi, 92).

The dynamics of politics also reinforces this tendency, this is why many scholars emphasise the role played by the radicals in galvanizing disheartened publics, or rather radical Islam as a "catalyst for have-not states".

"They perceive themselves under assault from three reigning ideas of the Western political system: free market capitalism, secular democracy and human rights, and the nation-state as the basic unit of international relations [...]. Yet for all their long-term validity as a basis for a new world order, these ideas [...] they will not deliver in the short to medium term for states under heavy pressure from their populations for quick, tangible improvement of economic and social life" (Ibidem.).

It is therefore difficult to imagine a more moderate interpretation of Islam, capable of regaining political initiative by taking it away from Islamic groups that base their strength on the call for cultural authenticity. "In short, we are talking about a fundamental struggle within Islam itself. If successful, a reform process would satisfy the Muslim preference for 'authenticity' in society: an Islamic basis and justification would exist for conformity with modern international practice without having to go outside the tradition. But the reality is that the political spectrum of Islamist politics under current conditions is not hospitable to strong reform tendencies within Islam [...]. The future of a strong Islamic reform movement [...] is therefore not bright" (Ibidem).

That said, to what extent does Islam influence the current contrasts within the Muslim world and between itself and the West?

Many admit that there is some theoretical reason in Islam to justify a state of permanent tension within the Muslim world, taking as an example, the concept of jihâd, which naturally draws the attention of those who postulate the theolog- 
ical hostility of Islam against the West. The word jihâd itself has not one sole fundamentalist interpretation and is not for their exclusive use, nor does it correspond to the incorrect journalistic simplification of holy war in place of the Quranic "striving in the path of God". There are at least two other meanings of the same term. In fact, in the Quran the root jid means the "inner struggle" leading man to spiritual fulfilment, as well as the "methodological effort" in the search of truth, from which the legal term ijtihâd derives. In particular, the root jid, with all its derivations, appears in 35 verses of the Quran: 22 as "general struggle", 10 as "act of war" and 3 as "spiritual elevation" (Allam, 2002: p. 125). But we must be very careful to avoid confusing elements of religious doctrine with the realities of life. Radicals will always exist in any society, and to justify their beliefs those radicals will turn to the "highest" laws of life and society-either to God, race, or the supposedly inexorable forces of history [...]. The problem for the West, therefore, lies not specifically in Islam but in the radical visions of all extremists within any such movement [...]. "Many are particularly hostile to the West [...], but that is an opposition of a political and cultural nature, rather than a theological one" (Fuller \& Lesser, 1996: p. 94). In fact, while extremist and visionary leaders can theoretically aim for the continued expansion of Islam throughout the world, the goal of the majority of Islamic religious leaders is rather to preserve Islam within the existing Muslim world.

Indeed, as a worldwide religion Islam has not conceived any expansion since the beginning of the colonial era. In this sense, it is no longer a faith in movement capable of new territorial acquisitions. Islamic activists are therefore mainly, and almost exclusively, focusing on the community to which they belong. As a matter of fact, today "jihâd is almost entirely being conducted within Islam, no longer in the border regions where it was traditionally conducted" (El-Kenz, 1991: p. 95).

In turn, any revolutionary vision of Islam in the world seems far removed from the minds of the majority of religious representatives, such as the Sunni traditionalists who are affiliated with the authoritative university of al-Azhar in Cairo. Nor can it be said otherwise with regard to $S h$ ism, where the growing opposition to the Khomeini's regime caused the failure of the top-down Islamisation of society being attempted since 1979 .

In summary, "today it is difficult to find in most Islamic circles, whether conventional or not, active support and ideas of permanent war between Islam and the West [...]. Few Muslims in their daily lives and in interaction with Westerners nourish any kind of concept of implacable hostility or the need for confrontation. The West is a daily reality in the lives of nearly all Muslims; it is a culture many of whose features Muslims admire [...]. Muslims know they must reach a compromise with the West, and they actually do so without hesitation" (Fuller \& Lesser, 1996).

Like all other religious books in history, the Quran and the Hadit of the Prophet lend themselves to be a rich source of doctrines, which can be used to justify different interpretations, even contradictory ones. 
Islam becomes "dangerous" to the extent that it is liable to provide a theoretical framework for extremism, in terms of exasperated conflict not only towards the West, but also towards Muslim regimes themselves. Contemporary Islamism has aimed above all to give voice to the serious hardships of the world in an ideological perspective, providing at the same time a social context and local institutions that would allow leverage to these problems by highlighting them and, at times, fuelling them.

But within the world and Muslim traditions there exist ideas-promoted by important "enlightened" religious leaders — that reconcile moderation, prudence and tolerance.

However, in addition to what has been said, it must be pointed out that at the moment institutional Islam still remains a prisoner of most Muslim states, either greedy for petrodollars, according to the effective expression dear to Mernissi and Etienne, or hegemonic power. Institutional Islam, which is not spontaneously criticising the limits and errors of the existing regimes, is in fact, considered prey to those same regimes, and at times defined by the radicals as "al-Islam al Amriki", that is, as "American Islam".

Given these premises, there does not currently seem to be any other opposition movement within the Muslim world capable of being as appealing to the underprivileged masses as the radical movement is.

As a result, only a religious institution that is independent enough to be able to represent a valid opposition to the State could be credible enough among the most afflicted populations, while preventing extremists from having the monopoly of political initiative.

In the absence of such an institutional reference, however, people will paradoxically rely on religion even more and more significantly, as people become aware of their own difficult living conditions compared to those enjoyed by most Westerners.

Therefore, religion itself, and by the very fact of relying on transcendent values that can be realised on earth, seems to be a suitable political instrument in unstable societies to mobilise hungry masses. Indeed, Semitic religions, and especially Islam, are particularly suitable for this political use, as they tend to dictate concrete and binding norms of "good governance" on society according to indisputable dogmatic truths.

\section{Conclusion}

In the long excursus on Islamic fundamentalism, Linz's powerfully expressed characteristic of the political use of religion emerges with arrogance. Religion, which reinterpreted in an ideological key, becomes the basis for legitimizing political power and an instrument of oppression and conflict. In order to better understand its origin we have seen how fundamentalism fits within the wider development of Islamic reformism. The phenomenon of Islamic fundamentalism, as we have examined, is just an aspect of the broader Islamic awakening. 
Nevertheless, it has gained more importance compared to the 90s, not only on a quantitative level, but also and above all because it stands as the "vanguard" of Islamism, a spearhead that claims to lead the Islamic recovery of the world as the repository of the true foundations of the faith and, therefore, of its authentic mission. The role played by Islamist fundamentalism today is even more alarming, considering its great allure, and its ability to activate militants and trigger anti-Western feelings, which make it a wide recruitment pool for the entrepreneurs of terror.

Islamic fundamentalism, as analysed above, is a movement in competition with other reformist and moderate groups of the "Islamic revivalism". It involves the two main souls and is stepping up to claim the hegemonic power within the Muslim framework, causing a clash within the religion across almost all Islamic countries. Although many call it a religious war, it is not insofar as Islamism is more of a political phenomenon than a religious one-it is probably an ideological clash with profound geopolitical repercussions. It is a defensive conflict in many ways aimed at rejecting what they consider a threat, but it is also a real offensive war aimed at conquering the world, according to their ideological setup.

Today, as in the past, the real ongoing conflict, regardless of the terror escalation, is not between Islam and the West, but predominantly within the Muslim civilisation. In the context of this conflict within the Muslim world, Islam as a theological fact is not the real problem.

\section{Conflicts of Interest}

The author declares no conflicts of interest regarding the publication of this paper.

\section{References}

Allam, K. F. (2000). L’Islam contemporaneo. In G.Filoramo (Ed.), Islam, Laterza: Roma-Bari. Allam, K. F. (2002). Islam Globale. Milano: Rizzoli.

Almond, G., Appleby, R., \& Sivan, E. (2006). Religioni forti. L'avanzata dei fondamentalismi nella scena mondiale. Bologna: Il Mulino.

Campanini, M. (1999). Islam e politica. Bologna: Il Mulino.

El-Kenz, A. (1991). Algerian Reflections on Arab Crises. Austin: Texas University Press.

Etienne, B. (2001) L'islamismo radicale. Milano: Rizzoli.

Fuller, G., \& Lesser, I. (1996). Geopolitica dell'Islam. Roma: Donzelli.

Guolo, R. (1999). L'Islam è compatibile con la democrazia? Roma-Bari: Laterza.

Linz, J., (2006). Democrazia e autoritarismo. Bologna: Il Mulino.

Qutb, S. (1983). Fî Zilâl al Qử ân. Il Cairo: Dârash-Shûruq.

Sacks, J. (2015). Not in God's Name: Confronting Religious Violence. Hachette: Hodder \& Stoughton.

Schmitt, C. (1972). Le categorie del politico. Bologna: Il Mulino.

Watt, W. M. (1988). Islamic Fundamentalism and Modernity. London: Routledge. 